\title{
UPAYA MENINGKATKAN AKTIVITAS DAN HASIL BELAJAR BAHASA INDONESIA POKOK BAHASAN TEKS CERITA (NOVEL) SEJARAH DENGAN MENGGUNAKAN MODEL PEMBELAJARAN STAD PADA SISWA KELAS XII IPS 1 SMAN 3 KOTABUMI TAHUN PELAJARAN 2018--2019
}

\author{
IDAWATI \\ Idawatisman3ktb@gmail.com
}

\section{SMAN 3 KOTABUMI}

\begin{abstract}
Low student learning outcomes are an indicator of this research. This study aims to increase the activities and outcomes of Indonesian language learning by using the STAD learning model in historical text material (novels) of class XII IPS 1 SMA Negeri 3 Kotabumi in the 2018-2019 academic year. The research was carried out in 2 cycles, namely for the material structure, content, value and language of historical story texts (novels) and elements, topics and frameworks of historical story texts (novels) where all cycles began planning activities followed by implementation and observation and ended with reflection. . Data collection techniques using cognitive tests and student attitude questionnaires obtained from each cycle, the results were analyzed whether there was an increase in each cycle. After doing research and data analysis, it was found that there was an increase in student learning outcomes and activities from cycle I to cycle II. For indicators of student learning outcomes there was an increase of $58 \%$ in cycle II when compared to cycle I. whereas for student activity in disciplinary indicators there was an average increase of 0.7, for indicators of cooperation the average increase was 1.05, indicators of courtesy. The average score was 0.56 and for the tolerance indicator the average increase was 1.16 and overall for student learning activities increased by 20.47.
\end{abstract}

Keywords: STAD, activity, Indonesian learning outcomes

\begin{abstract}
Abstrak: rendahnya hasil belajar siswa menjadi indicator dilakukannya penelitian ini. Penelitian ini memiliki tujuan untuk meningkatkan aktivitas dan hasil belajar bahasa Indonesia dengan menggunakan model pembelajaran STAD pada materi teks cerita (novel) sejarah siswa kelas XII IPS 1 SMA Negeri 3 Kotabumi tahun pelajaran 2018--2019. Penelitian dilaksanakan dalam 2 siklus yaitu untuk materi struktur, isi, nilai dan kebahasaan teks cerita (novel) sejarah dan unsur -unsur, topik dan kerangka karangan teks cerita (novel) sejarah dimana semua siklus diawali kegiatan perencanaan dilanjutkan pelaksanaan dan pengamatan serta diakhiri dengan refleksi. Tekhnik pengambilan data dengan tes kognitif dan angket sikap siswa yang diperoleh dari tiap siklus, hasilnya dianalisis apakah terjadi peningkatan pada setiap siklus. Setelah dilakukan penelitian dan analisis data diperoleh hasil yaitu terjadi peningkatan hasil belajar dan aktivitas siswa dari siklus I ke siklus II. Untuk Indikator hasil belajar siswa terjadi kenaikan sebesar 58\% pada siklus II jika dibandingkan dengan siklus I. sedangkan untuk aktivitas siswa pada indikatr disiplin terjadi rata-rata kenaikan sebesar 0,7 , untuk indikator kerjasama rata rata kenaikan sebesar 1,05, indikator santun rata -rata kenaika sebesar 0,56 dan untuk indikator toleransi rata-rata kenaikan sebesar 1,16 dan secara keseluruhan untuk aktivitas belajar siswa mengalami kenaikan sebesar 20,47.
\end{abstract}

Kata Kunci: $S T A D$, Aktivitas, Hasil Belajar Bahasa Indonesia 


\section{PENDAHULUAN}

Pendidikan pada dasarnya adalah usaha sadar untuk menumbuhkembangkan potensi sumber daya manusia peserta didik dengan cara mendorong dan memfasilitasi kegiatan belajar (Muhibbin, 2006). Namun, dewasa ini proses pembelajaran yang dilakukan tenaga pendidik di SMAN 3 Kotabumi cenderung hanya untuk mencapai target dari kurikulum hanya mementingkan nilai tanpa memperhatikan tingkat pemahaman konsep dimiliki oleh siswa. Kegiatan belajar-mengajar yang terjadi hanya terpusat pada guru, guru merupakan pusat informasi, biasanya metode yang digunakan berupa metode ceramah, siswa hanya duduk menerima semua informasi guru. Keadaan ini menyebabkan pembelajaran menjadi tidak kondusif, siswa tidak aktif, bosan dan tidak termotivasi memahami konsep materi yang dipelajari. Untuk menyelesaikan permasalahan tersebut dibutuhkan guru yang kreatif dalam melaksanakan kegiatan pembelajaran dengan cara melakukan variasi model pembelajarannya sehingga siswa tidak bosan, salah satu model yang bisa dilaksanakan yaitu model pembelajaran kooperatif tipe STAD.

Slavin (Rusman, 2012:213), model STAD (Student Team Achievement Division) merupakan variasi pembelajaran kooperatif yang paling banyak diteliti. Model ini juga sangat mudah diadaptasi, telah digunakan dalam Matematika, IPA, IPS, Bahasa Inggris, Teknik, dan banyak subjek lainnya, dan pada tingkat sekolah dasar sampai perguruan tinggi. Dian (2011) mengatakan "Pembelajaran ko-operatif tipe STAD adalah salah satu model pembelajaran kooperatif dimana siswa belajar dengan bantuan lembaran kerja sebagai pedoman secara ber-kelompok, berdiskusi guna memahami konsep-konsep, menemukan hasil yang benar".

Model kooperatif learning tipe STAD yaitu pembelajaran kooperatif yang mudah, dan sederhana untuk dipraktekkan oleh guru yang baru mulai menggunakan pembelajaran kooperatif. Dalam pembelajaran ini siswa digabungkan dalam suatu tim bersama empat orang dalam tim belajar yang merupakan kumpulan he-terogen menurut tingkat kemampuanya, jenis kelamin dan prilaku. Guru menya-jikan materi pelajaran kemudian siswa bekerja bersama-sama dalam tim serta harus dipastikan bahwa seluruh anggota tim menguasai materi pelajaran tersebut. Diakhir pembelajaran diadakan kuis untuk semua siswa tentang materi tersebut.

Pelajaran Bahasa Indonesia kelas XII tentang materi Teks Cerita (Novel) Sejarah merupakan materi yang cukup luas. Untuk 
mempelajarinya diperlukan pemahaman dan sumber referensi yang beraneka ragam. Rata-rata nilai Bahasa Indonesia siswa kelas XII IPS SMAN 3 Kotabumi pada tahun pelajaran 2018-2019 khu-susnya pokok bahasan Teks Cerita (Novel) Sejarah yaitu 70 yang masih di bawah nilai KKM bab tersebut sebesar 75. Hal ini terjadi karena kurangnya inovasi dari tena-ga pendidik. Keadaan inilah yang me-motivasi peneliti melakukan kajian yang berjudul "Upaya Meningkatkan Aktivitas dan Hasil Belajar Bahasa Indonesia Pokok Bahasan Teks Cerita (Novel) Sejarah dengan Menggunakan Model Pem-belajaran STAD Siswa Kelas XII IPS 1 SMAN 3 Kotabumi Tahun Pelajaran 2018-2019

"Rumusan permasalahan yang terdapat dalam penelitian ini adalah: Apakah ada peningkatan Aktivitas dan hasil belajar bahasa Indonesia pada pokok bahasan teks Cerita (Novel) Sejarah dengan menggunakan model pembelajaran STAD siswa kelas XII IPS 1 SMAN 3 kotabumi tahun pelajaran 2018-2019?

Tujuan pada penelitian ini adalah: meningkatkan aktivitas dan hasil belajar Bahasa Indonesia Pokok Bahasan Teks Cerita (Novel) Sejarah dengan menggunakan model pembelajaran STAD siswa kelas XII IPS 1 SMAN 3 kotabumi tahun pelajaran 2018-2019

Pembelajaran dengan model koperatif tipe STAD merupakan pen- dekatan pembelajaran kelompok yang paling sedehana dan lebih memfokuskan pada kegiatan dan interaksi diantara siswa yang saling mendukung, membantu dan memotivasi untuk bersama-sama menguasai materi pelajaran yang dipelajari secara maksimal serta pada akhirnya membantu meningkatkan prestasi belajar. Dalam memanfaatkan STAD dalam pembelajaran guru secara verbal atau teks memberikan informasi akademik kepada siswa.

Kelompok merupakan inti yang sangat penting dalam pembelajaran kooperatif tipe STAD karena didalam kelompok terjadi interaksi yang positif untuk bekerja sama mencapai tujuan kemampuan akademik yang diinginkan. Dengan adanya kelompok para siswa saling mendukung untuk saling bekerja sama dalam pembelajaran dan yang utama untuk mempersiapkan siswa dalam menyelesaikan suatu soal. Pembagian kelompok diatur oleh guru sedemikian rupa sehingga dalam kelompok terdiri dari beraneka ragam jenis siswa, yaitu siswa kemampuan tinggi, rendah atau sedang. Guru harus mempertimbangkan agar tidak terjadi pertentangan atau perselisihan di dalam kelompok.

Dalam suatu model pembelajaran selalu ada kendala dalam pelaksanaannya, setiap guru harus memperhatikan ini dan selalu berusaha untuk mengatasi kendala 
tersebut. Seperti dengan model pembelajaran yang lain yang tidak sempurna, model pembelajaran tipe STAD juga memiliki kendala serta kelemahan contohnya ada yang kurang aktif dalam pembelajaran, kurangnya waktu dan lain sebagainya. Dalam rangka meminimalkan kelemahan dan kendala dalam pelak-sanaan model pembelajaran kooperatif metode STAD, sebaiknya ada pembagian materi tertentu bagi setiap siswa, kemudian mereka bersama-sama bertukar informasi dan saling melengkapi. Selanjutnya untuk mengetahui hasil kolaborasi belajar para siswa sebaiknya guru melukan evaluasi di akhir pembelajaran tentang materi secara keseluruhan. Dengan cara ini diharapkan setiap anggota kelompok merasa bertanggung jawab dan termotivasi untuk menyelesaikan tugasnya serta berhasil mencapai tujuan bersama-sama dengan baik.

\section{METODE PENELITIAN}

Subyek dalam penelitian ini adalah siswa siswi kelas XII IPS 1 SMAN 3 Kotabumi tahun pelajaran 2018--2019 dengan jumlah peserta didik 34 orang. Kegiatan penelitian ini disesuaikan dengan bentuk penelitian tindakan kelas, penelitian ini dilakukan dalam upaya meningkatkan hasil belajar bahasa Indonesia peserta didik.

Hal ini relevan dengan pendapat Suryadi (2011), Penelitian Tindakan Kelas disingkat PTK atau Classroom Action Research adalah bentuk penelitian yang terjadi di dalam kelas berupa tindakan tertentu yang dilakukan untuk memperbaiki proses belajar mengajar guna meningkatkan hasil belajar yang lebih baik dari sebelumnya. Tahapan penelitian disusun dalam beberapa siklus. Siklus akan terhenti apabila keberhasilan pembelajaran telah didapat. Setiap siklus terdiri atas kegiatan perencanaan, pelaksanaan, pengamatan, dan diakhiri dengan refleksi. Siklus I dilaksanakan untuk materi struktur, isi, nilai dan kebahasaan teks cerita (novel) sejarah, setelah dilakukan pelaksanaan perlu diadakan refleksi untuk menemukan kendala yang ada disiklus I dan sebagai dasar agar tidak terulang kembali kekurangan/kelemahan yang ada disiklus I.

Untuk memperoleh data maka diperlukan suatu instrumen penelitian sebagai berikut:

1. Angket Kemampuan Afektif

Lembar Angket dirancang untuk mengetahui aktivitas sikap siswa dalam proses belajar mengajar menggunakan model pembelajaran STAD. Siswa 
diamati untuk indikator disiplin, kerjasama, santun dan toleransi.

\section{Tes Kemampuan Kognitif}

Tes kemampuan kognitif dilaksanakan di akhir siklus penelitian. Hasil dan nilaiyang diperoleh dari tes ini digunakan sebagai dasar untuk mengetahui tingkat hasil belajar siswa dan tingkat ketuntasan belajar bahasa indonesia

Penelitian ini dinilai berhasil jika terdapat peningkatan hasil belajar dan aktivitas belajar Bahasa Indonesia dalam materi teks cerita (novel) sejarah di atas kkm atau 75 siswa kelas XII IPS 1 SMAN 3 Kotabumi (MGMP http://www.raseko.com/2013/05/pengertian-kriteriaketuntasan-minimal.html)

\section{HASIL DAN PEMBAHASAN}

\section{Hasil}

Penelitian ini dilaksanakan dalam 2 siklus serta setiap siklus tersusun dari tahap perencanaan, tindakan, observasi dan refleksi. Dalam siklus I siswa dibagi dalam 4-5 orang dalam satu kelompok yang berbeda - beda dalam hal kemampuan, jenis kelamin dan keidiplinan, kemudian guru memberikan materi yang harus dipelajari siswa bersama-sama dalam satu kelompok.
Sebelum diskusi kelompok dimulai guru menjelaskan tentang langkah -langkah pembelajarannya, tujuan akhir dan tanggung jawab yang dimiliki oleh setiap kelompok. Setelah diskusi selesai diadakan kuis untuk mengetahui tingkat pemahaman siswa setelah pembelajaran, hasil kusi dan pengamatan aktivitas belajar menjadi data untuk pengolahan nilai. Setelah melakukan pengolahan data penilaian diperoleh hasil seperti di bawah ini.

Tabel 1 : Hasil Belajar

\begin{tabular}{|c|c|c|c|c|}
\hline \multirow{2}{*}{ siklus } & \multicolumn{2}{|c|}{ jumlah } & \multicolumn{2}{c|}{$(\%)$} \\
\cline { 2 - 5 } & tuntas & $\begin{array}{c}\text { tidak } \\
\text { tuntas }\end{array}$ & tuntas & $\begin{array}{c}\text { tidak } \\
\text { tuntas }\end{array}$ \\
\hline I & 6 & 28 & 18 & 82 \\
\hline II & 25 & 9 & 76 & 24 \\
\hline
\end{tabular}

Dari hasil penolahan nilai tes di akhir siklus diperoleh data pada siklus I ada 6 orang siswa atau $18 \%$ dengan nilai diatas 75 dan dikatakan telah menuntaskan hasil belajarnya, sedangkan bagi siswa tidak tuntas atau nilai belum mencapai KKM berjumlah 28 orang siswa atau $82 \%$. Pada siklus II terjadi kenaikan jumlah siswa yang tuntas atau nialai diatas KKm sebanyak 25 orang atau $76 \%$ serta siswa yang belum tuntas mengalami penurunan menjadi 9 orang atau $24 \%$. Dan secara keseluruhan jika dibandingkan antara siklus ke I dan siklus II terjadi kenaiakn hasil belajar siswa sebesar 58\%. Untuk Indikator aktivitas 
belajar siswa aspek diamati yaitu disipli, kerjasama, santun dan toleransi, data diperoleh dari pe-ngamatan guru dan dituangkan dalam lembar angket aktivitas siswa, setelah di-lakukan pengambilan dan pengolahan data diperoleh hasil sebagai berikut:

Tabel 2. Tabel perkembangan sikap dan aktivitas siswa

\begin{tabular}{|c|c|c|}
\hline $\begin{array}{c}\text { Sikap dan } \\
\text { aktivitas } \\
\text { siswa }\end{array}$ & $\begin{array}{c}\text { Siklus I } \\
\text { (rerata) }\end{array}$ & $\begin{array}{c}\text { Siklus II } \\
\text { (rerata) }\end{array}$ \\
\hline Disiplin & 3 & 3,7 \\
\hline Kerja sama & 2,85 & 3,8 \\
\hline Santun & 3,44 & 4,0 \\
\hline Toleran & 2,94 & 4,1 \\
\hline
\end{tabular}

Berdasarkan tabel di atas, diperoleh rata-rat sikap dan aktivitas belajar siswa sebagai berikut; (a) Rata - Rata kelas Siklus $1=57,63$ (b) Rata - rata kelas siklus II $=$ 78,1

\section{Pembahasan}

Kegiatan belajar mengajar dengan menggunakan model koperatif tipe STAD, siswa dikelompkkan secara heterogen kemudian diberi tanggung jawab untuk bersama-sama memahami materi yang ditugaskan guru, diharapkan dalam proses pembelajaran terjadi kerjasama dan saling melengkapi untuk bersama-sama mencapai tujuan utama yaitu memahami materi yang sedang dipelajari.
Kegiatan siklus I terlebih dahulu dimulai dengan perencanaan yaitu pembuatan RPP, soal ujian formatif diakhir pembelajaran dan lembar angket aktivitas siswa. Langkah berikutnya yaitu pelaksanaan, guru membagi kelas dalam beberapa grup atau kelompok yang terdiri dari 4-5 orang dengan kemampua, ras, kelamin yang berbeda-beda, sebelum melaksanakan pembelajaran guru terlebih dahulu menjelaskan urutan kegiatan apa yang akan dilakukan siswa serta tujuan akhir dalam satu kelompok yang akan dicapai secara bersama-sama. Selama pembelajaran Sikap siswa pada materi Teks Cerita (Novel) Sejarah dengan menggunakan model pembelajaran STAD membantu siswa dalam memahami materi yang dipelajari. Pada siklus I dilaksanakan pembelajaran sejalan dengan sintak pada rencana program pengajaran (RPP) yang disusunnya. Diawali kegiatan pembuka dan apersepsi guru menyampaikan konsep tentang struktur, isi, nilai dan kebahasaan teks cerita (novel) sejarah. Selanjutnya siswa berdiskusi dalam kelompok tentang materi yang diperolehnya, dan menpresentasikan hasil diskusinya. Kemudian guru menguji hasil diskusi dengan memberi pertanyaan pada anggota kelompok secara acak. Untuk mengukur tingkat keberhasilan 
pembelajaran guru mengadakan sebuah tes formatif kepada peserta didik.

Dari hasil tes siklus I terlihat jumlah siswa dengan nilai diatas KKMnya sebesar $18 \%$ hal ini masih belum mencapai target yang telah ditetapkan. Hasil analisis angket siklus I kegiatan belajar dengan menggunakan model pembelajaran STAD mulai menunjukkan sikap disiplin (3), kerja sama $(2,85)$, santun $(3,44)$ dan toleran $(2,94)$ selama proses pembelajaran Bahasa Indonesia serta untuk rata-rata kelas sebesar 57,63 termasuk dalam kategori cukup. Pada awal siklus I ada beberapa kendala yaitu:

1. Siswa masih belum memahami peranan kelompok sehingga diskusi yang dilakukan seadanya.

2. Diskusi lebih didominasi oleh siswa yang aktif serta cenderung menguasai diskusi.

Pada siklus kedua guru menjelaskan keemahan dan kesimpulan teks cerita (novel) sejarah. Selanjutnya siswa berdiskusi dalam kelompok tentang materi yang diperolehnya, dan menjelaskan materi yang didapat di depan kelas, disini peran guru adalah menjembatani dan menyemangati setiap siswa anggota kelompok agar memahami materi yang diberikan, untuk meminimalkan kendala keaktifan siswa yang tidak merata maka guru menganjurkan dalam kelompok diberi pembagian tugas materi perindividu, yang nantinya siswa tersebut bertanggungjawab untuk memahami materi tersebut dan membantu teman dalam kelompoknya agar memahaminya juga, diharapkan dengan pembagian ini ada tanggung jawab dalam diri masing-masing siswa serta bersamasama saling melengkapi materi sehingga secara keseluruhan materi dapat dipahami dalam kelompk tersebut. Setelah materi seluruh siswa terkumpul dalam kelompok, guru menguji hasil diskusi dengan memberi pertanyaan pada anggota kelompok secara acak. Di setiap akhir pembelajaran siswa diberi suatu tes formatif untuk menegetahui hasil pembelajaran hari ini..

Pada siklus ini dengan sendirinya siswa telah memahami peranaannya dalam kelompok sehingga tidak menyia-nyiakan fungsi dari kelompok para siswa memiliki tanggung jawab dan kerja sama yang baik dan saling melengkapi untuk mendapatkan pengetahuan dan memecahkan masalah yang ada. Adapun langkah yang diambil peneliti untuk mengatasi kendala yang terjadi di siklus I yaitu terus menyemangati siswa untuk aktif berdiskusi dan memotivasi siswa untuk berusaha banyak membaca untuk memahami materi, membantu pembagian materi dalam tiap kelompok.

Dari hasil pemberian tes di siklus II jumlah siswa dengan nilai telah tuntas pembelajarannya sebesar $76 \%$. Hasil ini telah mencapai target yang ditetapkan dan hasil angket pada siklus II menunjukkan 
bahwa terjadi peningkatan sikap disiplin sebesar 3,7, kerjasama 3,8, santun 4, dan toleransi 4,1 serta rata-rata aktivitas kelas sebesar 78,1 masuk kategori baik. Pada siklus ke 2 kesulitan yang ada pada siklus 1 dapat diminimalkan, seperti diskusi yang tidak maksimal.

\section{SIMPULAN}

Setelah melakukan serangkai penelitian dan kajian hasil dan pembahasan maka PTK dengan judul "Upaya Meningkatkan Aktivitas dan Hasil Belajar Bahasa Indonesia Pokok Bahasan Teks Cerita (Novel) Sejarah dengan Menggunakan Model Pembelajaran STAD Siswa Kelas XII IPS 1 SMAN 3 Kotabumi Tahun Pelajaran 2018-2019” dapat disimpulkan seperti uraian berikut:

1. Terjadi peningkatan ketuntasan belajar untuk proses belajar mengajar dengan menggunakan model pembelajaran STAD siklus 1 (18\%) hingga siklus 2 (76\%), dan rerata hasil belajar siswa yang tuntas juga naik sebesar 58\%

2. Aktivitas belajar siswa untuk indikator disiplin meningkat sebesar 0,7 yaitu 3,0 pada siklus I menjadi 3,7 pada siklusII
3. Ada peningktan aktivitas belajar untuk indikator kerjasama sebesar 0,95 yaitu 2,85 di siklus I menjadi 3,8 pada siklus II

4. Aktivitas belajar siswa indikator santun mengalami kenaikan yaitu sebesar 0,56 yaitu 3,44 di siklus 1 dan 4 di siklus 2

5. Ada kenaikan aktivitas belajar siswa untuk indikator toleransi yaitu sebesar 1,16 yaitu 2,94 pada siklus I dan menjadi 4,1 pada siklus II

6. Dari hasil angket terlihat bahwa kegiatan belajar mengajar dengan menerapakan model pembelajaran kooperatif tipe STAD mampu membantu peningkatan aktivitas siswa pada sikap disiplin , kerjasama, santun dan toleran dengan rata-rata aktivitas kelas sebesar $57,63 \%$ disiklus I serta meningkat di siklus II sebesar $78,1 \%$ sehingga diambil kesimpulkan bahwa penerapan model pembelajaran tipe STAD mampu membantu meningkatkan aktivitas belajar siswa pada materi Teks Cerita (Novel) Sejarah. 


\section{DAFTAR PUSTAKA}

Dian, A.R. (2011). Pembelajaran Kooperatif Tipe STAD dalam Matematika.[online].tersedia:http://kangdarukanti11januari.blogspot.com/2011/01/pem belajaran- kooperatif-tipe-stad-dalam.html.

MGMP (Musyawarah Guru Mata Pelajaran) http://www.ras-eko.com/2013/05/pengertiankriteria-ketuntasan-minimal.html.

Muhibbin, Syah. (2006) Psikologi Belajar, Jakarta: PT Raja Grafindo Persada.

Rusman (2012). Model-model Pembelajaran: Mengembangkan Profesionalisme Guru, RajaGrafindo Persada, Jakarta

Suyadi (2010). Panduan Penelitian Tindakan Kelas, Diva Press, Yogyakarta. 